\title{
South Korean Government's Role in Public Diplomacy: A Case Study of the Korean Wave Boom
} Sofia Trisni ${ }^{1}$, Putiviola Elian Nasir ${ }^{2}$, Rika Isnarti ${ }^{3}$, Ferdian $^{4}$

${ }^{l}$ International Relations, Universitas Andalas, Padang, Indonesia

${ }^{2}$ International Relations, Universitas Andalas, Padang, Indonesia

${ }^{3}$ International Relations, Universitas Andalas, Padang, Indonesia

${ }^{4}$ Pascasarjana, Universitas Andalas, Padang, Indonesia

\begin{tabular}{l}
\hline ARTICLE INFORMATION \\
\hline \\
\hline SUBMISSION TRACK \\
\hline Recieved : 14, January, 2019 \\
Final Revision : 15, May, 2019 \\
Available Online: 30, May, 2019 \\
\hline KEYWORD \\
\hline Korean wave, popular culture, public diplomacy
\end{tabular}

KATA KUNCI

Korean wave, budaya populer, diplomasi publik

CORRESPONDENCE

E-mail: sofidinara@gmail.com

\begin{abstract}
Korean wave has became a current booming popular culture; reaching all continents of the world. The phenomenon is the result of cooperation from various actors, namely state and non-state actors. This paper aims to determine the role of the South Korean government in the accomplishments of the Korean wave to date, by studying the literature that focuses on the Korean wave success. We conducted library research to some related articles and government's policy paper in order to get our finding. Our research concludes that the South Korean government acts as a stimulator, regulator and facility provider for the cultural industry to develop. While the success of the Korean wave in penetrating the world market is the result of the formulation of strategies and promotions conducted by non-state actors involved in the process of producing the Korean wave.
\end{abstract}

\section{ABSTRAK}

Korean wave telah menjadi budaya populer yang sedang booming saat ini; menjangkau semua benua di dunia. Fenomena tersebut merupakan hasil kerjasama dari berbagai aktor, yaitu aktor negara dan non-negara. Tulisan ini bertujuan untuk menentukan peran pemerintah Korea Selatan dalam pencapaian Korean wave hingga saat ini, dengan mempelajari literatur yang fokus pada keberhasilan Korean wave. Tulisan ini menggunakan studi pustaka terhadap beberapa artikel terkait dan dokumen kebijakan pemerintah untuk mendapatkan temuan. Tulisan ini menyimpulkan bahwa pemerintah Korea Selatan bertindak sebagai stimulator, regulatir dan penyedia fasilitasi bagi industri budaya untuk berkembang. Sedangkan keberhasilan Korean wave dalam menembus pasar dunia adalah hasil dari perumusan strategi dan promosi yang dilakukan oleh aktor non-negara yang terlibat dalam proses Korean wave.

\section{Introduction}

Korean wave is taking over the world. In May 2018, the New York Times released an article titled "BTS Becomes the First K-Pop Act to Top Billboard Album Chart". This news piece shared the success story of BTS, a South Korean boy band, in penetrating the American market. In the same column, it was reported that BTS was the first music group outside of the United States to reach the top position on the American Billboard in the last 12 years, which was previously "occupied" by Il Divo in 2016. Apart from outrivaling famous 
names such as Justin Bieber, Ariana Grande and Selena Gomez on the Billboard top charts, BTS became the first South Korean music group invited to speak at the UN session. ${ }^{1}$ Meanwhile Korean Dramas such as the Descendant of the Sun, were able to attract viewers from 32 countries, with a total of 1 billion viewers per each episode on iQiyi in 2016. ${ }^{2}$ This presents a small example South Korea's popular culture success in penetrating the world, after in 2012, PSY struck the global music industry by being first place in Britain's pop charts and number two in America. ${ }^{3}$

The United States and Great Britain have not been the only countries affected by this popular culture, Indonesia has also been heavily experiencing Korean wave effects. One of the examples is the success of South Korean cultural festival in Palembang on August 13, 2018. The festival arranged by the Korean Cultural Center Indonesia (KCCI) captivated 3,000 people, higher than the 1,000 attendees that KCCI targeted. ${ }^{4}$ In addition, Indonesia has the largest South Korean popular culture fan base in Asia (Milia, 2015). This indicates the Indonesian people's high interest in the cultural products exported by the country of ginseng.

Hallyu or more familiar as Korean wave or Hallyu describes the phenomenon of South Korean popular culture outbreak outside of

\footnotetext{
${ }^{1}$ BBC, BTS : Who are they and how did they become so successful?, view online 5 Oktober 2018, $20: 10$ https://www.bbc.co.uk/newsround/45721656,

2 J.A. Son, "Descendants of the Sun Heads to 32 countries", Koreanet 4 April 2016 view online 10 Oktober

2018 http://www.korea.net/NewsFocus/Culture/view?articl eId $=134818$

${ }^{3}$ The Economist, Bubbly pop, view online 5 Oktober 2018 ,

20:19

https://www.economist.com/banyan/2012/10/02/bubbl y-pop,

${ }^{4}$ Y. Safitiri, "Korean culture event in Palembang draws thousands of K-pop fans", The Jakarta Post, 13 August 2018, view online 25 Nov 2018, https://www.thejakartapost.com/life/2018/08/13/korea n-culture-event-in-palembang-draws-thousands-of-kpop-fans.html
}

its own country. ${ }^{5}$ Korean wave includes a wide range of cultural products such as drama series, movies, k-pop, dance, games, culinary, fashion dan language (Jang and Won, 2012). ${ }^{6}$ Korean wave's popularity is gradually spreading; with the estimation reaching East Asia, South East Asia, Africa and Europe.

There is a unique element present in the Korean wave boom. Although the Korean wave is a component of South Korea's Public Diplomacy, the authors find that the success of the Korean wave is not accompanied by increased interest in accessing South Korean government programs in the city of Padang in 2017. This means, there is a separation of objects by fans in this city between cultural products and their home countries (South Korea). This indication generated interest; specifically, in understanding the government's role in the success of the Korean wave. This then becomes the basis for recognizing the reason behind Korean wave fans enthusiasm with Korean wave products, but not accompanied by increased curiosity about the South Korean government program. To understand government's role in Korean wave production, this article is divided into four segments; the introductory section as the first part, Research Methodology in the second part and in the Discussion and Analysis in third part, we present the importance of public diplomacy as the rationale for why countries are competing to use public diplomacy. Further in the third part we also provide an explanation of South Korea's policies regarding Korean wave including the state actors involved, and also the discussion of South Korean government role in the industry. The fourth part is a conclusion of our writing.

\footnotetext{
5 N.P.E Suryani, "Korena wave sebagai instrument soft power untuk Memperoleh Keuntungan Ekonomi Korea Selatan”, Global Vol. 16 No.1 Mei 2014

${ }^{6}$ G.Jang and W.K. Paik, "Korean wave as Tool for Korea's New Cultural Diplomacy", Advances in Applied Sociology, 2012. Vol.2, No.3, 196-202
} 


\section{Research Method}

We conducted library research to fulfil our aims. We collected some related articles to Korea's government involvement in Korean wave industry and we also look into Korean government policy that was written on diplomatic white paper, government's website and policies that quoted by some expert. There are thirty three articles and policy that we studied. From our observing to those articles, we then put these articles into some grouping under some coding. Those coding brought us into some government's effort such as stimulator, regulator and facility provider. We based our grouping according to the definition offered by the dictionary. For the definition of a stimulator, Oxford dictionary tells that stimulator is "A person or thing that encourages the development of or increased activity in a state or process". ${ }^{7}$ It means, for every sentence that indicates activities in accordance with this definition will group into stimulator. Further, there are three definitions offered by Oxford dictionary for Regulator ; First, "a person or body that supervises a particular industry or business activity", Second , "a device for controlling the rate of working of machinery or for controlling fluid flow, in particular a handle controlling the supply of steam to the cylinders of a steam engine" and lastly "a device for adjusting the balance of a clock or watch in order to regulate its speed". 8 Similar to the first point, we looked into the sentence that indicated the role as a regulator with paying attention to the above definition. In addition, provider means "a person or thing that provides something". 9 We did the same treatment for the third definition.

\footnotetext{
${ }^{7}$ Oxford Dictionaries, accessed 13 May 2019, https://en.oxforddictionaries.com/definition/stimulator

${ }^{8}$ Oxford Dictionaries, accessed 13 May 2019, https://en.oxforddictionaries.com/definition/stimulator

${ }^{9}$ Oxford Dictionaries, accessed 13 May 2019 , https://en.oxforddictionaries.com/definition/provider
}

\section{Result and Discussion}

Before explain the result of our research, we would like to begin with the discussion about Public Diplomacy as Korean wave's activities are claimed as part of Public Dipomacy by the South Korean government.

\section{The Significance of Public Diplomacy}

In today's era, achieving state interests can not only be done by strengthening hard power assets, but can also be achieved by strengthening soft power assets. The term soft power was coined by Joseph Nye, who explains soft power as an approach using attraction in order to attract other parties to voluntarily follow our desires without feeling forced. ${ }^{10}$ Furthermore, Nye ${ }^{11}$ explained that the use of soft power assets is important because "a country may obtain outcomes it wants in world politics because other countries want to follow it, admitting its values, emulating its example, and / or aspiring to its level of prosperity and openness ". This means that through the use of soft power, the state no longer has to struggle to achieve its interests, because people of the target country who have admired and fallen in love with that specific country, will voluntarily follow its wishes without being forced to. Furthermore, Nye ${ }^{12}$ describes that a country's soft power assets /resources lie in its culture, values and policies. Still according to Nye, public diplomacy is an approach that states can use to develop soft power.

Public diplomacy has various definitions, but in essence, all of these definitions agree that public diplomacy is an

\footnotetext{
${ }^{10}$ J. Nye, "Public Diplomacy and Soft Power", Annals of the American Academy of Political and Social Science, Vol. 616, PublicDiplomacy in a Changing World Mar., 2008, pp. 94-109, p.94

${ }^{11}$ J. Nye, 2018

${ }^{12}$ J. Nye, 2018
} 
effort to reach foreign public. Sharp ${ }^{13}$ states that public diplomacy is "the process of direct relations with people in a country that is pursued to advance the interest and extend the values of those being represented". Berridge $^{14}$ defines that public diplomacy is a white propaganda, which is used by the state to influence other countries by winning (the heart) of its people. Rana ${ }^{15}$ suggests that public diplomacy is "activities through governments, working with non-state agencies, reach out to publics and nonofficial actors abroad, covering information, culture, education and the country image". Furthermore Emilia ${ }^{16}$, described public diplomacy as "any effort conducted by the government of a country towards the international public". The above definitions provide an illustration of the difference between traditional diplomacy and public diplomacy; which unlike traditional diplomacy that focuses on the relationship between governments ( $G$ to $G$ ); public diplomacy emphasizes the relationship with foreign public. Moreover, the government is not the only public diplomacy actor. In reality, public diplomacy actors have been developing and increasing; which currently also includes non-state actors. ${ }^{17}$

Despite the expansion of contributing actors, basically public diplomacy still aims to win the hearts and minds of the public; which according to Nye is an effective way to create soft power. Amr Hady in $\mathrm{Cho}^{18}$

\footnotetext{
${ }^{13}$ P. Sharp, "Revolutionary States, Outlaw Regimes and the Techniques of Public Diplomacy" dalam Melissen (eds), The New Public Diplomacy : Soft Power in International Relations, Palgrave macmillan, 2005

${ }^{14}$ G.R Berridge, Diplomacy : Theory and Practice, Palgrave Macmillan, New York 2010

15 K.R Rana, 21st Century Diplomacy : A

Practicioner's Guide, Continuum, London, 2011

${ }^{16}$ R.Emilia, Praktek Diplomasi, Baduose Media, 2013

17 N. J. Cull, Public Diplomacy: Lessons from the Past. California: FIGUEROA PRES,2009

18 YY. Cho, "Public Diplomacy and South Korea's Strategies", The Korean Journal of International Studies, Vol. 10, No.2 (Dec 2012), pp.275-296
}

agreed to this thought and wrote that "through a bottom-up political mechanism, civil society has a pressure on the government policymaking, and this will indirectly influence one 's national security and prosperity". The importance of winning the hearts and minds of foreign people becomes crucial based on the fact that these people are expected contributors of their country's policy changes. The argument becomes more compelling with the increasing potential of public's involvement in the process of a state's policy making in current democratic era. Therefore, public diplomacy becomes a popular tool used by many states; one of them is South Korea.

South Korea is a country that highly regards its public diplomacy implementation. The last four South Korean presidents believed that the use of culture as an asset to achieve the country's interests is the precise strategy. ${ }^{19}$ South Korean government's concern for cultural policy flourished since 1990, when the desire to become a developed country emerged in South Korea. $^{20}$ In their article published in the "International Journal of Cultural Policy", Kwon and $\mathrm{Kim}^{21}$ presented their findings on the long-standing policies of the South Korean government starting in 1990 to support the advancement of their cultural industries. It provides an explanation why the booming of South Korean cultural products in today's global market cannot be separated from the role of the government through regulations made to facilitate developing of cultural industries. This means that the country's concern for its cultural industry development is very high, and

\footnotetext{
19 O. Krasnyak, ,2017, Evolution of Korea's Public Diplomacy, USC Center on Public Diplomacy, https://uscpublicdiplomacy.org/blog/evolutionkoreas-public-diplomacy, viewed 1 June 2018, 12:23 WIB

${ }^{20} \mathrm{~S}$. Kwon and J. Kim, "The cultural industry policies of the Korean government and the Korean Wave, International Journal of Cultural Policy 20 : 4, 31 Dec 2014, pp.422-439, 2014

${ }^{21}$ Kwon and Kim, 2014
} 
without the support given through regulations or the accelerated development of other industries, South Korea might not have achieved their current success.

When President Lee Myung-bak came into office in 2008, he launched the slogan "Global Korea". This presents an interesting point of how South Korea highly perceives its cultural industry. "Global Korea" became a branding elevating the position of South Korea as a developed country, unlike the popular notion of South Korea at that time, as a poor country that has been involved in civil war. ${ }^{22}$ The country believes this image which disturbs them; the image of being poor and related to civil war, produces negative views of South Korea. During his tenure, President Lee wanted to bring South Korea to a more advanced economic level, as stated in his first state address in February 2008 "That is the vision of a Great Korea that Lee Myung-bak's administration will work for. The miracle will continue. The legend will go on ". ${ }^{23}$ Still in the same speech, President Lee stressed the importance of developing their cultural industry, by reasoning the use of this asset to actualize Global Korea ${ }^{24}$ :

We must develop our competitiveness in our contents industry, thereby laying the foundation to become a nation strong in cultural activities. An increase in income will lead to a rise in cultural standards, which in turn heightens our quality of life. Through culture we are able to enjoy life, through culture we are able to communicate with each other and through culture, we will be able to advance together. The new Administration will do its best to bring the power of our culture into a full blossom in this globalized setting of the 21 st century.......... Our traditional culture, when coupled together with our technological prowess, will no doubt transmit to the world an image of a more attractive Korea.
Furthermore, to accomplish this desire of "Global Korea", President Lee's government formed a council named "Presidential Council on Nation Branding (PCNB)" which was mandated to execute 10 action points, where one of the points was "to adopt a 'Korean wave 'program'. ${ }^{25}$ In this period, the Korean wave which had pioneered its success starting in the 1990s in China ${ }^{26}$ began to be adopted by the state as part of its policy. Lee's government intended to maintain the popularity that has been achieved by the Korean wave. ${ }^{27}$ This was based on the positive results contributed by cultural products which were able to help the country achieve prosperity in the economics sector and image improvement.

Lee Myung-bak's policy towards Korean wave has been continued by the South Korean government to date. The South Korean Ministry of Foreign Affairs website explains that "Hallyu (the Korean wave) serves as an important element of Korea's public diplomacy". Meanwhile, public diplomacy is one of South Korean's diplomacy focus used to achieve its interests as described in the following foreign ministry website ${ }^{28}$ :

....the Ministry of Foreign Affairs (MOFA) has moved beyond the sphere of traditional government-oriented diplomacy by increasing its focus on public diplomacy, which includes reaching out to the foreign public through the arts, knowledge sharing, media, language, and aid.

South Korea's attention towards its public diplomacy is also evident in the large budget allocation for its implementation. In 2016, MOFA's budget was recorded at 17.8

\footnotetext{
${ }^{25}$ J.V. John, 2015

${ }^{26}$ G. Jang and W.K. Paik, 2012

${ }^{27}$ J.V. John, 2015

${ }^{28}$ Website Kementerian Luar Negeri Korea Selatan http://www.mofa.go.kr/eng/wpge/m 5474/contents.do
}

\footnotetext{
22 J.V. John, "Globalization, National Identity and Foreign Policy : Understanding "Global Korea", The Copenhagen Journal of Asian Studies 33(2), 2015,

${ }^{23}$ Hankyoreh, Full text of Lee's inaugural speech, view online http://english.hani.co.kr/arti/english_edition/e_nationa 1/271850.html 6 Oktober 2018, 9:29

${ }^{24}$ Hankyoreh, 2018
} 
billion won / 16.18 million dollars. ${ }^{29}$ This amount continues to be increased by the government, as reported by their foreign ministry website.

The Korean wave adoption as an element of public diplomacy was based on the ambition to make South Korea a developed country with a positive image. Cultural aspects are considered as one of the tools to achieve this target, given the rich culture owned by this country. Aside from the progress in the economic sector, the Korean wave is also considered a soft power asset, which basically also supports the progress proclaimed by South Korea.

\section{South Korean Government's Role in the Korean Wave Success}

In this section, the authors attempt to observe the role of government in the success achieved by Korean wave. The success of Korean wave has become a very interesting phenomenon to study, given its extraordinary appeal to various groups. The results of our 2017 study demonstrated that $28 \%$ of Korean wave fans in Padang spent between 1-3 hours a day watching Korean cultural products, while another $25 \%$ spent 3-5 hours per day. The amount of time they have allocated to watch Korean cultural products is quite high, therefore it is compelling to understand the role of the government in achieving that success.

The South Korean President is known as a president who tends to the implementation of his public diplomacy. The Korean wave success yielded positive response during President Lee Myung-bak's government. President Lee Myung-bak included Korean Wave into the PCNB program, a council formed by the

\footnotetext{
${ }^{29}$ S. Lee, "Korea’s Public Diplomacy Needs Better Coordination and Strategies, Korea Focus, 13 Jannuary 2015, view online 10 Oktober 2018 http://www.koreafocus.or.kr/design2/layout/conte nt_print.asp?group_id=105736
}

government for branding his country. This was the government's initial step in institutionalizing the Korean wave, which at first was more of a phenomenon of success of cultural products that were administered by non-state actors. The subsequent presidents also gave great attention to Korean wave. The South Korean Foreign Ministry website on the public diplomacy section clearly stated Korean wave as an important element of the country's public diplomacy. This statement was strengthened by discussion of Korean wave in the 2016 Diplomatic White Paper. The discussion of Korean wave in important state documents indicate the importance of this topic for the government.

Furthermore, other roles executed by government can be seen by referring to a number of government policies at the outset of this emerging cultural industry's idea. Examples of this initial policy are assistance in finding investors and idea exchanges about potentially globalizing popular culture. The system changes implemented by the government in the 1980s provided space for the Chaebol / conglomerates to invest in the Korean wave industry. ${ }^{30}$ In this case, government provides assistance by finding funding for this industry because through its regulations, conglomerates such as Samsung, Daewoo, Hyundai, LG and SK began to enter the industry and distribute their funds. ${ }^{31}$ A specific example was investment allocated to SM Entertainment, which gave SM the opportunity to have various auditions to find the best members for the boy band under its label; one of these boy band groups was

\footnotetext{
${ }^{30}$ S. Jun and D.Shim, "Social distribution : K-pop fan practices in Indonesia dan the 'Gangnam Style' phenomenon", International Journal of Cultural Studies Vol 17(5), 2014, 485-501; Jang and Paik, “ Korean Wave as Tool for Korea's New Cultural Diplomacy", Journal Advances in Applied Sociology Vol.2, No.3, 2012, pp.196-202

${ }^{31}$ S. Kwon \& J. Kim, "The Cultural Industry Policies of the Korean government and the Korean wave", Intenational Journal of Cultural Policy 20:4, 422439, 2014
} 
H.O.T. ${ }^{32}$ In addition, the Kim Dae-jung government (1998-2003) gave the permission for Japenese Culture to enter his country, providing an exchange of creative content between the two countries. ${ }^{33}$

It can be assumed that the government was able to fill the gap of funding to help this cultural industry to go global, because the preparation of the production process until distribution uses a large amount of funds. The conglomerates involvement in this industry is considered as effective strategy; supporting an industry that was once simple to stretch and develop. Meanwhile, the entry of Japanese cultural content provides lessons and inspiration for the development of South Korea's cultural industry. Based on this strategy, the South Korean government has been regarded as effective and responsive by maximizing the existing situation and issuing appropriate policies.

There is also another role of the government in supporting the development of this country's culture industry. Youtube, Twitter and other virtual world programs are factors that support the success of Korean wave. The research we conducted in 2017 at universities in Padang also indicated the same results. It cannot be denied that the power of promotion today is greatly influential on internet technology that can reach public around the world in a short time. Lee Myung-bak's government (20082013) created policies that included strengthening ICT. ${ }^{34}$ Strengthening this ICT structure facilitated the cultural industry to manage promotions through the use of internet networks. K-pop companies take advantage of technological developments through YouTube and Facebook as a medium to promote their products ${ }^{35}$, all of

\footnotetext{
${ }^{32}$ S. Jun and D.Shim, 2014

33 F. Istad, "A Strategic Approach to Public Diplomacy in South Korea" in Kadir Ayhan (ed), Korea's Public Diplomacy, Seoul, Korea : Hangang Network, 2016

${ }^{34}$ Kwon and Kim, 2013

${ }^{35}$ S.Jun and D.Shim, 2014
}

this strategy require the power of internet networks and the government responded quickly by strengthening their ICT networks. The government is once again responsive in understanding the right media in promoting their cultural products by strengthening the infrastructure associated with internet use.

Moreover, the South Korean government shows its support for the Korean wave by awarding the actors / actress involved in this cultural industry as ambassadors for various activities. This effort is considered as government promotion support to their cultural products. ${ }^{36}$ For example, the Wonder Girls were named Korean Food Ambassador, Kim Hyun Joong as the UN Ambassador for the Social Welfare Program and Hyun Bin as Korean Defense Ambassador. ${ }^{37}$ Indonesian actress Dewi Sandra, was named Korean Tourism ambassador for Indonesia. ${ }^{38}$ Subsequently, actor Song Joong-ki, who was the male lead of the drama "Descendant of the Sun" was appointed as honorary ambassador for Korean tourism in $2016 .{ }^{39}$ Although these types of appointments can be seen as symbiosis of mutualism, where the government also gain benefit from assigning these actors and actresses who have won global reputation with fans who are widely spread internationally, it cannot be denied that this policy can also be considered as the government's efforts to help maintain the popularity of Korean wave.

Other policies issued by the South Korean government in supporting their

36 T.D Effendi, "K-Pop and J-Pop Influences to University Students in Malang, East Java-Indonesia : A Comparative Public Diplomacy Studies" Andalas Journal of International Studies, Vol.1 No.2, 2012, pp.182-196

${ }^{37}$ T.D Effendi, 2014

38 T.D Effendi, 2014

${ }^{39}$ I.C Chang, "Descendants's Actor Invites You Into Story of Korea", Koreanet, 26 Mqy 2016, view online $10 \quad$ Oktober 2018, http://www.korea.net/NewsFocus/Culture/view?articl eId $=134793$ 
cultural industries are related to the creation of various institutions; both institutions directly under the government or institutions affiliated with the government. These councils and institutions are an extension of government in coordination, promotion and execution of various South Korean cultural products. It has been previously mentioned that President Lee Myung-bak's government established a nation branding council named PCNB. PCNB is an example of an institution directly under the government, where the coordination is directly under the authority of the president. ${ }^{40}$ PCNB then created King Sejong Institute, located in various countries, focusing on the Korean language learning. ${ }^{41}$ In Indonesia, this institution was established in collaboration with the National University, with funds sponsored by the South Korean government. ${ }^{42}$ In 1995 , government founded the Culture Industry Bureau to monitor the development of the country's cultural industry. ${ }^{43}$ In addition, there are various other institutions such as KCC (Korean Cultural Center), KOICA (Korea International Cooperation Strategy) and KOFICE (Korean Foundation for International Cultural Exchange). $\mathrm{KCC}$ is a language and cultural centre with programs such as Korean language learning and movie screenings ${ }^{44}$, KOICA is associated with the cooperation and business development ${ }^{45}$ while KOFICE is concentrate on student

\footnotetext{
${ }^{40}$ Choi and Kim 2014; F. Istad 2016; Kwon and Kim 2013

41 D.Y Choi, and P.S. Kim, "Promoting a Policy Initiative for Nation Branding : The Case of South Korea", Journal of Comparative Asian Development 13:2, 2014, pp.346-368

${ }^{42}$ MPR UNAS, "UNAS Korea Jajaki Program King Sejong Institute", Marketing and Public Relations Universitas Nasional 17 May 2017, view online 25 Nov 2019 http://mpr.unas.ac.id/unas-korea-jajakiprogram-king-sejong-institute/

${ }^{43}$ G. Jang and W.K. Paik

${ }^{44} \mathrm{KCC}$ website http://id.koreanculture.org/id/6/contents/341 accessed 8 May 2019

${ }^{45}$ KOICA website

https://www.koica.go.kr/koica_en/index.do accessed 8 May 2019
}

exchange schemes. ${ }^{46}$ The South Korean government prepares various institutions to support the advancement of the cultural industry; these institutions can either be government institutions or institutions affiliated with the government.

Apart from the government's support previously described, there are also other policies implemented by the South Korean government to advance its cultural industry. One example is by prioritizing the growth of strategic industries, compiling a series of development plans, providing financial assistance and controlling labor availability. ${ }^{47}$ During Kim Dae Jung's term between 1998 - 2002, the government built infrastructure needed by developing firms by providing funding support. ${ }^{48}$ Specific plans and policies to aid cultural products penetrate the global market were conceived during Roh Moo-hyun's government. ${ }^{49}$ Furthermore in 2015, the government bank, Korean Development Bank (KDB), provided funding of 100 billion won to the Korea Broadcasting Station (KBS) for creative content. $^{50}$

However, behind the efforts made by the South Korean government, there are various gaps raised by experts regarding this role which is the lack of coordination between the government and implementing institutions. The government is required to provide direction, coordination with stakeholders and promotion of activities related to the cultural industry. ${ }^{51}$ The point here is that the government must improve coordination between state ministries and affiliated organizations. ${ }^{52}$ Coordination between these actors will be conducted by forming a "control tower" to coordinate information between various ministries and

\footnotetext{
${ }^{46}$ KOFICE website http://eng.kofice.or.kr/ accessed 8 May 2019

${ }^{47}$ S. Kwon \& J. Kim, 2013

${ }^{48}$ Baek in Kwon and Kim, 2013

${ }^{49}$ S. Kwon \& J. Kim

${ }^{50}$ F. Istad, 2016

${ }^{51}$ F. Istad, 2016

${ }^{52}$ F. Istad, 2016
} 
organizations. ${ }^{53}$ Furthermore, $\mathrm{Cho}^{54}$ argues that the government needs to form an organized public diplomacy goal and to form effective strategies. Other than coordination problems, there is also criticism towards the continuity of policy implementation, where suitable policies cannot be maintained for a long period of time due to the change of leaders. An example of this is the PCNB dismantling by President Park Geun-hye during her tenure. ${ }^{55}$

There is an indication that the institutions formed by the South Korean government, as described in the paragraph above, did not receive sufficient coordination from the government therefore inhibiting the implementation synergy of the industry. There is a possibility that this lack of control, interference and coordination from the government has caused its programs to become unpopular among our respondents in 2017. When non-state actors conduct their activities without coordination with the government, the goal of these missions are to achieve economic interests and does not include the government's mission in implementing public diplomacy.

There are also claims that the success of Korean wave is the result of the non-state actors hard work. Focusing on the success of Korean wave, there are several statements indicating that the success achieved by the cultural industry is the contribution of private actors. This means, the government did not play a significant role in the success of Korean wave. This can be seen from the statement of the Minister of Culture, Sports and Tourism Kim Jongdeok in $2016^{56}$ :

We, the Korean government and the culture ministry, support the work they want to make, but we would not take any role or whatsoever as a decision maker or in getting involved in the actual working process at all. It's the working people, I mean, film makers or singers, who take the lead in actually promoting the Korean wave outside South Korea. The government is just

\footnotetext{
${ }^{53}$ S. Lee, 2015

${ }^{54}$ YY. Cho, 2012

${ }^{55}$ F. Istad, 2016

56 J.A. Son, 2015
}

putting a little bit of stepping stones so that they can jump up and move forward. That's all we do.

A similar argument was also made by Jung and Shim $^{57}$ who explained that the success achieved by producers such as SM, YG and JYP is the result of the implementation of a well-organized and excellent production and distribution strategy by the producers. The above statement provides an understanding that the role of the government in the success of Korean wave is not large, unlike the role of the private actors who were involved in its creation and distribution. Chae Jiyoung, senior researcher at the Korea Culture and Tourism Policy Institute, added that the success was not because of the government or the Korean broadcaster, but because of suitable market conditions for Korean cultural products export motivated by a competitive domestic market. ${ }^{58}$

The above descriptions generated several explanations. First, the government fully understands the importance of the cultural industry for the country's image and economy, therefore the government then gives more attention to this industry. This attention is manifested by providing support to develop the industry, starting from funding policy making, opening investment for private actors, building various infrastructures to support the development of the cultural industry, including the provision of trained workers. Second, the government established institutions and affiliations to support the cultural industry. Unfortunately, there are indications that there are still gaps in the government's role. Experts consider these institutions as uncoordinated with no clear strategic goal and no similar objective targeted by state actors and non-state actors. Moreover, the success of the Korean wave is claimed to be the success achieved by private actors, not as a result of government effort. To sum up, the government plays a major

\footnotetext{
${ }^{57}$ S.Jung and D Shim, 2014

${ }^{58}$ D. Shim, 2008
} 
role in stimulating and facilitating the cultural industry to develop, while for its execution, it is the non-state actors who are instrumental in achieving the success of Korean wave.

\section{Conclusion}

The Korean wave is a cultural industry that involves many actors; both state and non-state actors such as producers, actors, actresses, distributors and others involved in the production process from the beginning to the promotion and distribution process. In addition to these actors, the Korean wave success cannot be separated from the support and role provided by the South Korean government. The South Korean government is a government that is well aware of the great opportunities brought by their cultural industries, provides large support in order to develop this industry. This paper has outlined the role conducted by the government in supporting the Korean wave success. Government's dominant role can be seen from the strategic policy implemented by government, such as policies to facilitate smooth investment from conglomerates, which makes it possible for this industry to obtain financing to improve their quality; granting permission for Japanese cultural products to enter Korea, which can be seen as an opportunity for Koreans to produce creative ideas for cultural industry development; state institutions designation to implement public diplomacy, including establishing affiliated institutions; building various infrastructures that facilitate the advancement of this industry such as strengthening ICT networks and stimulating other strategic industries; include Korean wave as an element of their public diplomacy; help promote Korean wave actors / actresses by appointing them as ambassadors for various government activities and numerous other roles related to these descriptions.

Although indications support South Korean government's various roles is in accordance with its position as a state regulator, there are several weaknesses of this role. This paper underlines coordination and consistency as the deficiency. This research resulted in implications surrounding the government's lack of control over government affiliated institutions or purely private institutions, in brief, poorly planned execution. Additionally, problems arise from government inconsistency due to change in state leadership; consequently, hindering long-term implementation of programs. In conclusion, the South Korean government acts as Korean wave's stimulator, regulator and facility provider. However, it is nonstate actors involved in Korean wave production who capably plays the role of executor.

\section{REFERENCES}

BBC, BTS : Who are they and how did they become so successful?, view online https://www.bbc.co.uk/newsround/45721656, 5 Oktober 2018, $20: 10$

Berridge, G.R, Diplomacy : Theory and Practice, Palgrave Macmillan, New York 2010

Chang, I.C, "Descendants's Actor Invites You Into Story of Korea", Koreanet, 26 Mqy 2016, view online $10 \quad$ Oktober 2018 , http://www.korea.net/NewsFocus/Culture/view?articleId=134793

Cho, Yun Young, "Public Diplomacy and South Korea's Strategies", The Korean Journal of International Studies, Vol. 10, No.2 (Dec 2012), pp.275-296 
Sofia Trisni, Putiviola E. Nasir, Rika Isnarti, Ferdian | South Korean Government's Role in Public Diplomacy: A Case Study of the Korean Wave Boom

Choi, Dae Yong and Kim, Pan Suk, "Promoting a Policy Initiative for Nation Branding : The Case of South Korea", Journal of Comparative Asian Development 13:2, 2014, pp.346-368

Cull, N. J, Public Diplomacy: Lessons from the Past. California: FIGUEROA PRES, 2009

Diplomatic Whitepaper of South Korea, 2016

Effendi, Tonny Dian, "K-Pop and J-Pop Influences to University Students in Malang, East Java-Indonesia : A Comparative Public Diplomacy Studies" Andalas Journal of International Studies, Vol.1 No.2, 2012, pp.182-196

Emilia, Ranny, Praktek Diplomasi, Baduose Media, 2013

Gunjoo, Jang dan Won K. Paik, "Korean wave as Tool for Korea's New Cultural Diplomacy”, Advances in Applied Sociology, 2012. Vol.2, No.3, 196-202

Hankyoreh, Full text of Lee's inaugural speech, view online http://english.hani.co.kr/arti/english_edition/e_national/271850.html 6 Oktober 2018, 9:29

Istad, Felicia, "A Strategic Approach to Public Diplomacy in South Korea" in Kadir Ayhan (ed), Korea's Public Diplomacy, Seoul, Korea : Hangang Network

Jang and Paik, "Korean Wave as Tool for Korea's New Cultural Diplomacy", Journal Advances in Applied Sociology Vol.2, No.3, 2012, pp.196-202

John, Jojin V, "Globalization, National Identity and Foreign Policy : Understanding "Global Korea", The Copenhagen Journal of Asian Studies 33(2), 2015, 38-57

Jung, Sun dan Shim, Doobo, "Social distribution : K-pop fan practices in Indonesia dan the 'Gangnam Style' phenomenon", International Journal of Cultural Studies Vol 17(5), 2014, 485-501

Krasnyak, Olga,2017, Evolution of Korea's Public Diplomacy, USC Center on Public Diplomacy, https://uscpublicdiplomacy.org/blog/evolution-koreas-public-diplomacy, viewed 1 June 2018, 12:23 WIB

Korean Cultural Center http://id.korean-culture.org/id/6/contents/341

Kwon and Kim, "The cultural industry policies of the Korean government and the Korean Wave, International Journal of Cultural Policy 20 : 4, 31 Dec 2014, pp.422-439

Lee, Sook-jong, "Korea's Public Diplomacy Needs Better Coordination and Strategies, Korea Focus, 13 Jannuary 2015, view online 10 Oktober 2018 http://www.koreafocus.or.kr/design2/layout/content_print.asp?group_id=105736

Milia, Jana, "Indonesia Dipengaruhi oleh Korean wave juga loh!”. Kompasiana, view online https://www.kompasiana.com/milimilia/552883046ea83405718b456b/indonesia-jugadipengaruhi-korean-wave-loh 19.08.2018

Nye, "Public Diplomacy and Soft Power", Annals of the American Academy of Political and Social Science, Vol. 616, PublicDiplomacy in a Changing World Mar., 2008, pp. $94-109$

Oxford Dictionaries, accessed 13 May 2019, https://en.oxforddictionaries.com/definition/stimulator London, 2011

Rana, Kishan R, 21st Century Diplomacy : A Practicioner's Guide, Continuum,

Savitri, Yulia, Korean culture event in Palembang draws thousands of K-pop fans, The Jakarta Post, view online http://www.thejakartapost.com/life/2018/08/13/korean-cultureevent-in-palembang-draws-thousands-of-k-pop-fans.html , 5 Oktober 2018, 19:28 
Sofia Trisni, Putiviola E. Nasir, Rika Isnarti, Ferdian | South Korean Government's Role in Public Diplomacy: A Case Study of the Korean Wave Boom

Son, J.A, "Descendants of the Sun Heads to 32 countries", Koreanet 4 April 2016 $\begin{array}{llll}\text { view } & \text { online } & 10 & \text { Oktober }\end{array}$ http://www.korea.net/NewsFocus/Culture/view?articleId=134818

Seung-Ho Kwon \$ Joseph Kim (2014), "The Cultural Industry Policies of the Korean government and the Korean wave", Intenational Journal of Cultural Policy 20:4, 422-439, 2014

Shim, Doboo, "The Growth of Korean Cultural Industries and the Korean wave" in Chua BH and Iwabuchi K (eds) (2008) East Asian Pop Culture: Analysing the Korean wave. Hong Kong: Hong Kong University Press.

Sohn, Jiae, 2017, "Content producers lead Korean wave", Korea.net http://www.korea.net/NewsFocus/Culture/view?articleId=134924 view online 1 June 2018, $14: 32$

Safitiri, Y, "Korean culture event in Palembang draws thousands of K-pop fans", The Jakarta Post, 13 August 2018, view online 25 Nov 2018, https://www.thejakartapost.com/life/2018/08/13/korean-culture-event-in-palembang-drawsthousands-of-k-pop-fans.html

Sisario, Ben, BTS Becomes the First K-Pop Act to Top Billboard Album Chart, the New York Times, 28 May 2018, view online https://www.nytimes.com/2018/05/28/arts/music/bts-no-1-billboard.html , 5 Oktober 2018, 19:12 Wib

Sharp, Paul, "Revolutionary States, Outlaw Regimes and the Techniques of Public Diplomacy" dalam Melissen (eds), The New Public Diplomacy : Soft Power in International Relations, Palgrave macmillan, 2005

Suryani, Ni Putu Elvina, Korena wave sebagai instrument soft power untuk Memperoleh Keuntungan Ekonomi Korea Selatan, "Global Vol. 16 No.1 Mei 2014

The Economist, Bubbly pop, view online https://www.economist.com/banyan/2012/10/02/bubbly-pop, 5 Oktober 2018, 20:19

Universitas Nasional, "King Sejong Institute Akan Menjadi Pusat Studi Korea di Jakarta" , 18 Juli 2017, view online 11 Oktober 2018 https://www.unas.ac.id/berita/kingsejong-institute-akan-menjadi-pusat-studi-korea-di-jakarta/

Website Kementerian Luar Negeri Korea Selatan http://www.mofa.go.kr/eng/wpge/m_5474/contents.do 